OPEN ACCESS

Edited by:

Fatima Baltazar.

University of Minho, Portugal

Reviewed by:

Lucie Brisson,

Inserm UMR1069Équipe Nutrition,

Croissance et Cancer, France

Hsueh-Wei Chang,

Kaohsiung Medical University, Taiwan

${ }^{*}$ Correspondence:

Ana M. Gil

agil@ua.pt

Specialty section:

This article was submitted to Cancer Metabolism,

a section of the journal

Frontiers in Oncology

Received: 03 August 2020

Accepted: 21 September 2020

Published: 12 October 2020

Citation:

Carneiro TJ, Martins AS,

Marques MPM and Gil AM (2020)

Metabolic Aspects of Palladium(II)

Potential Anti-Cancer Drugs.

Front. Oncol. 10:590970.

doi: 10.3389/fonc. 2020.590970

\section{Metabolic Aspects of Palladium(II) Potential Anti-Cancer Drugs}

\author{
Tatiana J. Carneiro ${ }^{1,2}$, Ana S. Martins ${ }^{1,2}$, M. Paula M. Marques ${ }^{2,3}$ and Ana M. Gil ${ }^{1 *}$ \\ ${ }^{1}$ Department of Chemistry, Center for Research in Ceramic and Composite Materials (CICECO)-Aveiro Institute of Materials \\ (CICECO/UA), University of Aveiro, Campus Universitário de Santiago, Aveiro, Portugal, 2 "Molecular Physical Chemistry" \\ R\&D Unit, Department of Chemistry, University of Coimbra, Coimbra, Portugal, ${ }^{3}$ Department of Life Sciences, University of \\ Coimbra, Coimbra, Portugal
}

This mini-review reports on the existing knowledge of the metabolic effects of palladium $[\mathrm{Pd}(\mathrm{II})]$ complexes with potential anticancer activity, on cell lines and murine models. Most studies have addressed mononuclear Pd(II) complexes, although increasing interest has been noted in bidentate complexes, as polynuclear structures. In addition, the majority of records have reported in vitro studies on cancer cell lines, some including the impact on healthy cells, as potentially informative in relation to side effects. Generally, these studies address metabolic effects related to the mechanisms of induced cell death and antioxidant defense, often involving the measurement of gene and protein expression patterns, and evaluation of the levels of reactive oxygen species or specific metabolites, such as ATP and glutathione, in relation to mitochondrial respiration and antioxidant mechanisms. An important tendency is noted toward the use of more untargeted approaches, such as the use of omic sciences e.g., proteomics and metabolomics. In the discussion section of this mini-review, the developments carried out so far are summarized and suggestions of possible future developments are advanced, aiming at recognizing that metabolites and metabolic pathways make up an important part of cell response and adaptation to therapeutic agents, their further study potentially contributing valuably for a more complete understanding of processes such as biotoxicity or development of drug resistance.

Keywords: palladium, complexes, chelates, anti-cancer activity, metabolism

\section{INTRODUCTION}

The discovery of the important antitumor activity of cisplatin [cis-diamminedichloroplatinum(II), cis- $\left.\mathrm{Pt}\left(\mathrm{NH}_{3}\right)_{2} \mathrm{Cl}_{2}, \mathrm{cDDP}\right]$ (1), a complex that targets DNA resulting in the formation of intra- and inter-strand DNA cross-links and triggering apoptotic cell death, led to it becoming the first successful metal-based anticancer drug (2). This prompted much interest in inorganic compounds as potential antineoplastic agents, platinum [Pt(II)] complexes remaining some of the most efficient chemotherapeutic drugs used in the clinic. However, such compounds are typically associated to serious systemic toxicity and acquired resistance (mainly via interaction with glutathione and metallothioneins) (3). Therefore, other metal complexes have been tested, namely containing ruthenium (4, 5), titanium (6), gold (7), and palladium, $\mathrm{Pd}(8-11) . \mathrm{Pd}(\mathrm{II})$ compounds have attracted much attention due to the similarity of the metal center to $\mathrm{Pt}(\mathrm{II})$ (electronic structure and 
coordination chemistry) $(12,13)$. Such complexes have shown favorable cytotoxic activity despite their higher lability compared to $\mathrm{Pt}(\mathrm{II})$ analogues $(10,11)$. In vivo stability of $\mathrm{Pd}(\mathrm{II})$ antitumor complexes relies on strongly coordinating ligands (e.g., dithiocarbamates, polydentate linear amines) and reasonably nonlabile leaving group(s) $(13,14)$. Both mono- and polynuclear Pd-complexes (i.e., containing one or more than one metal centers) have been synthesized and characterized (811, 13), along with heterometallic Pt/Pd-complexes (di- and trinuclear), in order to improve antineoplastic response and patient survival (15). In contrast to mononuclear metal agents, which can only bind (covalently) to one or two sites at their main pharmacological target (DNA bases), polynuclear compounds may interact with DNA at several sites on the double helix (via short or long range interactions depending on the nature of the ligands), inducing more severe and less repairable damage. In addition, development of polynuclear agents is based on the assumption that they may lead to interactions with multiple biological targets, simultaneously (e.g., sulfurdonor biomolecules, thioethers, thiols), thus restricting the induced deleterious side effects.

The $\mathrm{Pd}(\mathrm{II})$ complexes tested so far in relation to their antitumor activity have, mostly, been characterized in terms of cytotoxic and antiproliferative properties toward different tumor cell lines $(15,16)$, as well as to their DNA- or protein-binding abilities $(17,18)$. The knowledge of the ability of metal complexes and, in particular, $\mathrm{Pd}(\mathrm{II})$ complexes, to disrupt and induce adaptations in cell/organism metabolism is still scarce, in spite of its importance for the evaluation of the more global effects of these potential new antineoplastic agents. In this context, further and untargeted metabolic studies are of great value to unveil new disruptions in cellular metabolism resulting from exposure to complexes. Indeed, increasing interest is noted in further understanding the metabolic response of tumoral (and occasionally healthy) cell lines or tissues to drugs, both in vitro and in vivo. In this mini-review, the specific metabolic effects of Pd(II) complexes will be addressed, noting the complexes' impact on different genes, proteins or metabolite levels, subsequently interpreted as related to specific deviant metabolic pathways. Reports solely based on typical cytotoxicity/cell proliferative actions or DNA and protein binding are not included in this review, which intentionally gathers only the studies that include some reference to metabolic effects.

\section{IN VITRO STUDIES OF THE METABOLIC IMPACT OF Pd(II) COMPLEXES}

Table 1 lists the studies that report the impact of mono- and polynuclear $\mathrm{Pd}(\mathrm{II})$ complexes on some aspect of in vitro or in vivo metabolism, while the chemical structures of the corresponding $\mathrm{Pd}(\mathrm{II})$ complexes are shown in Table S1 (to guide the reader through the structural characteristics of these compounds). It becomes clear that most of the reported studies have addressed mononuclear Pd(II) complexes, often using cisplatin as a reference, and have been conducted in in vitro conditions. However, a more recent interest is noted in binuclear $\mathrm{Pd}(\mathrm{II})$ complexes, while some of the existing reports also describe comparison of results obtained in vitro with those registered in vivo in murine models. The text below is, when possible, organized chronologically, for each type of palladium complex investigated.

\section{Mononuclear Pd(II) Complexes}

An early study tested curcumin, the main yellow pigment of turmeric, as a ligand, together with 4,4'-dinonyl-2,2'-bipyridine (bipy) (19) (Table 1). Curcumin is believed to play several beneficial roles on human health, e.g., anti-inflammatory and antioxidant. The action of the [(bipy) $\mathrm{Pd}(\mathrm{Pcurc})]\left[\mathrm{CF}_{3} \mathrm{SO}_{3}\right]$ complex on several human prostate cancer lines revealed induction of apoptosis (with caspase-3 activation), associated with production of reactive oxygen species (ROS) and mitochondrial membrane depolarization. Interestingly, the complex did not seem to affect DNA structure or the activity of the DNA-repair enzyme PARP, contrary to the free curcumin ligand. This demonstrates the importance of ligand complexation, which in the case of $[($ bipy $) \mathrm{Pd}(\mathrm{Pcurc})]\left[\mathrm{CF}_{3} \mathrm{SO}_{3}\right]$, seems to determine intracellular mechanistic action. Also tested on prostate cancer cells (this time of the PC-3 cell line), a luminescent $\mathrm{Pd}(\mathrm{II})$ complex, $[\mathrm{Pd}(\mathrm{L}) \mathrm{Cl}]$, with acyclic tridentate ligand quinoline-2-carboxaldehyde-2-pyridylhydrazone, also revealed caspase- 3 activation as indicative of cell apoptosis (20). These effects were associated with cell cycle modulation indicated G2/M phase arrest and increased cytochrome $c$ expression, indicative of a deviant mitochondrial pathway.

Breast cancer cell lines have been the target of many studies testing the anti-cancer action of Pd(II)-based complexes. An earlier report addressed the action of a $\mathrm{Pd}(\mathrm{II})$ complex with saccharinate (sac) and 2,2':6',2'-terpyridine (terpy), [Pd(sac) (terpy)](sac) $\bullet 4 \mathrm{H}_{2} \mathrm{O}$, on two metabolically distinct breast cancer cell lines: estrogen-receptor-positive MCF-7 and triple-negative MDA-MB-231 (metastatic) (21). The authors report, for the first time to their knowledge, the increased expression of specific genes and proteins related to cell death receptors. An increment in the protein corresponding to the DR5 cell death receptor gene was interpreted as indicative that activation of cell death receptors by the $\mathrm{Pd}(\mathrm{II})$ complex is the main mechanism of apoptosis induction. However, in vitro results revealed different behaviors for the two cell lines, with MCF-7 cells becoming more actively apoptotic than MDA-MB-231 cells. The latter responded to the complex with reduced ability for tubules formation (and, hence, formation of cell networks), which may reflect an ability of the $\mathrm{Pd}(\mathrm{II})$ complex to reduce metastasis formation in triplenegative breast cancer cells. A few years later (25), the same authors published a full biochemical and proteomic study of the same complex on MDA-MB-231 cells, compared to human lung adenocarcinoma (A549) and epithelial cervical cancer (HeLa) cell lines. About 30 proteins were identified with altered expression levels in MDA-MB-231 cells, as a result of complex exposure. These proteins were suggested to impact on multiple cellular processes, e.g., energy metabolism, double strand break repair mechanisms, membrane trafficking, protein degradation 
TABLE 1 | List of metabolism-related studies of $\mathrm{Pd}(\mathrm{II})$ complexes tested in vitro or in vivo.

$\operatorname{Pd}(\mathrm{II})$ complexes and ligands (L)

Cell line/animal

model

\section{In vitro studies}

Mononuclear [(bipy) $\mathrm{Pd}(\mathrm{Pcurc})]\left[\mathrm{CF}_{3} \mathrm{SO}_{3}\right]$; L: pure curcumin (Pcurc), 4,4'-dinonyl-2,2' -bipyridine (bipy)

$[\mathrm{Pd}(\mathrm{L}) \mathrm{Cl}]$; L: acyclic tridentate quinoline-2carboxaldehyde-2-pyridylhydrazone

$\left[\mathrm{Pd}(\mathrm{sac})\left(\right.\right.$ terpy)](sac) $4 \mathrm{H}_{2} \mathrm{O}$; L: saccharinate (sac), 2,2':6',2"'-terpyridine (terpy)

$\mathrm{Pd}(\mathrm{MCO})_{2}$ (compared to Pt(MCO) $)_{2}$ and cDDP); L: 2cyano-2-isonitroso- $N$-morpholylacetamide [Pd(acac) $)_{2}$ (compared to cDDP); L: bisacetylacetonate (acac)

Pd(diethyl dithiocarbamate) ${ }_{2}$ (compared to Pt(II) analogue and other symmetrical $\mathrm{Pt}(\mathrm{II})$ and $\mathrm{Ni}(\mathrm{II})$ complexes); L: diethyl dithiocarbamate $\mathrm{Pd}(\mathrm{sac})\left(\right.$ terpy)](sac) $4 \mathrm{H}_{2} \mathrm{O}$; L: saccharinate (sac), 2,2':6',2"'-terpyridine (terpy)

[Pd $\left.\left(\mathrm{L}^{1}\right)_{2}\right],\left[\mathrm{Pd}\left(\mathrm{L}^{2}\right)_{2}\right],\left[\mathrm{Pd}\left(\mathrm{L}^{3}\right)_{2}\right],\left[\mathrm{Pd}\left(\mathrm{L}^{4}\right)_{2}\right]$ (compared to cDDP); L: 2-(arylazo)phenol with different $R$ and $R^{\prime}$ : $L^{1}: R, H ; R^{\prime}=\mathrm{CH}_{3}, L^{2}: R, \mathrm{CH}_{3}, H ; R^{\prime}=H, L^{3}: R$, $\mathrm{CH}_{2} \mathrm{CH}_{3} ; \mathrm{R}^{\prime}=\mathrm{H}, \mathrm{L}^{4}: \mathrm{R},\left(\mathrm{CH}_{2}\right)_{2} \mathrm{CH}_{3} ; \mathrm{R}^{\prime}=\mathrm{H}$

$\left[\mathrm{Pd}(\mathrm{sac})_{2}(\mathrm{dppm})\right],\left[\mathrm{Pd}(\mathrm{sac})_{2}(\mathrm{dppe})\right],\left[\mathrm{Pd}(\mathrm{dppm})_{2}\right](\mathrm{sac})$ ${ }_{2}$, $\left[\mathrm{Pd}(\mathrm{dppe})_{2}\right](\mathrm{sac})_{2}$

(compared to Pt(II) analogues and cDDP);

L: saccharinate (sac), 1,1-bis(diphenyl phosphino) methane (dppm),1,2-bis(diphenyl phosphino)ethane (dppe)

Polynuclear $\quad \mathrm{Pd}_{2} \mathrm{Spm}$ [compared to $\mathrm{Pt}(\mathrm{II})$ analogue and cDDP]; L: spermine (Spm)

$\mathrm{Pd}_{2}\left[\mathrm{~S}_{(-)} \mathrm{C}^{2}, \mathrm{~N}-\mathrm{dmpa}\right]_{2}$ ( $\mu$-dppe) $\mathrm{Cl}_{2}$ (compared to cDDP); L: N,N-dimethyl-1-phenethyl-amine (dmpa), 1,2-ethanebis(diphenyl phosphine) (dppe)

$\mathrm{Pd}_{2} \mathrm{Spm}, \mathrm{Pd}_{2}$ BENSpm (compared to $\mathrm{Pt}_{2}$ CPENSpm) L: spermine (Spm), $N^{1}, N^{11}$-bis(ethyl) norspermine (BENSpm), $N^{1}$-cyclo-propylmethyl- $N^{11}$ ethylnorspermine (CPENSpm)

$\mathrm{Pd}_{2} \mathrm{Spm}$ (compared to $\mathrm{Pt}$ analogues and cDDP); L: spermine (Spm)
LnCaP, PC3, DU145 (prostate cancer)

PC3 (prostate cancer)

MCF-7, MDA-MB-231

(breast cancer)

(comparison to in vivo)

HeLa (cervical cancer)

H460 (non-small-cell lung cancer)

(more lines in other studies and comparison

to in vivo)

K562 (leukemia)

MDA-MB-231 (breast cancer), A549 (lung cancer), HeLa (cervical cancer)

A549 (lung cancer), HeLa (cervical cancer), PA-1 (teratocarcinoma)

MCF-7 (breast cancer), A549 (lung cancer), DU145, HCT116 (colon cancer), BEAS-2B (bronchial epithelial)

A2780, A2780/CP (ovarian cancer, CP: cDDP resistant) B16F10-Nex2 (murine melanoma) (more lines for other studies and comparison to in vivo)

MCF-10A (normal-like breast epithelial), JIMT-1, L56BR-C1 (breast cancer)

MDA-MB-231 (breast cancer)
- Apoptosis (caspase-3 activation)

- $\quad \uparrow$ ROS levels (and $\downarrow$ GSH), JNK phosphorylation, GSTp1 downregulation

- Mitochondrial membrane depolarization, upregulated Bax downregulated $\mathrm{Bcl}-2$ proteins

- Hindered PARP activation, no effect on DNA (contrary to

Pcurc alone)

- Apoptosis (caspase-3 activation)

- G2/M phase cell cycle arrest, cell growth inhibition

- Mitochondrial pathway triggered, cytochrome $c$ release, higher caspase-3 activity

- $\uparrow$ expression of DR4/DR5 cell death genes, DR5 protein

- Possible anti-invasive activity by prevention of tubule

formation in MDA-MB-231 (metastatic)

- Apoptosis only in MCF-7 (non-metastatic)

- Unspecified different metabolic impact compared to cDDP family, probably averting negative side effects

- Apoptosis, via ER stress, with CHOP upregulation

- $\downarrow \mathrm{Ca}^{2+}$ levels, $\uparrow$ misfolded protein in ER

- Upregulation of IRE1 signaling, caspases activation

- Cytosolic antioxidant defense enzymes (GST, GPX, PTK, CAT) inhibition pattern, dependent on metal-complex

- Pd complex: good antioxidant and antitumor activity

- MDA-MB-231: 30 proteins with altered expression levels and impacting on multiple pathways, including energy metabolism, double strand break repair mechanisms, membrane trafficking, protein degradation and apoptosis

- $\uparrow$ ROS levels in all cell lines

- $\left[\mathrm{Pd}\left(\mathrm{L}^{2}\right)_{2}\right]$ : apoptosis, increased sub-G1 cell cycle population, induced mitochondrial dysfunction - $\uparrow$ ROS levels, mitochondrial membrane depolarization, cytochrome $c$ release, caspase overexpression, Bax overexpression, $\mathrm{Bcl}-2$ under-expression

- Cationic Pd-dppm and Pd-dppe: more active in all cells

- Neutral/cationic Pd-dppm complexes: apoptosis through caspases-3/7 activity, B-phase cell arrest, $\uparrow R O S$ levels

- Affects SMO, arginase 2, down-regulates NRF-2

- $\downarrow$ biogenic PAs putrescine, spermidine, spermine

- Reacts with protein thiol groups in mitochondrial membrane, changes membrane potential, induces Bax translocation into mitochondria

- Mitochondria and ER damage (changed $\mathrm{Ca}^{2+}, \mathrm{ATP}$, endonucleases levels)

- Caspases activation

- L56Br-C1: Pd 2 BENSpm decreased PAs levels, increased

SSAT activity

- $\mathrm{Pd}_{2} \mathrm{BENSpm}$ is selectively cytotoxic for breast cancer cells, with low toxicity for non-neoplastic MCF-10A cells

- $\mathrm{Pd}_{2}$ Spm: $\downarrow \mathrm{GSH}$ levels (L56Br-C1 most sensitive)

- $\mathrm{Pd}_{2} \mathrm{Spm}$ and $\mathrm{Pt}_{2} \mathrm{Spm}$ : distinct cytotoxicity pathways, $\uparrow$ lipids, changes in DNA/protein structures

- $\uparrow$ Thymine; $\downarrow$ adenine, cytosine, guanine, deoxyguanine, deoxyribose

Ref.

(Continued) 
TABLE 1 | Continued

\begin{tabular}{|c|c|c|c|c|}
\hline & Pd(II) complexes and ligands (L) & $\begin{array}{l}\text { Cell line/animal } \\
\text { model }\end{array}$ & Main metabolic observations & Ref. \\
\hline & $\begin{array}{l}\mathrm{Pd}_{2} \mathrm{Spm} \text { (compared to cDDP; single and Dox/Mtx } \\
\text { combined administration); L: spermine (Spm) }\end{array}$ & $\begin{array}{l}\text { MG-63 (osteosarcoma), } \\
\text { HOb (osteoblasts) }\end{array}$ & $\begin{array}{l}\text { * Pd2Spm alone: no apoptosis, less and reversible changes } \\
\text { in MG-63 ( } \downarrow G S H \text {, inositol, } \uparrow \text { hypoxanthine, } \downarrow U X P, \uparrow P C), \\
\text { changes amino acid levels in HOb } \\
\text { * Combined Pd2Spm: apoptosis, changes in lipids, choline } \\
\text { compounds, amino acids, nucleotides, GSH, inositol, } \\
\text { hypoxanthine (antioxidant defense) }\end{array}$ & (31) \\
\hline \multicolumn{5}{|l|}{ In vivo studies } \\
\hline \multirow[t]{2}{*}{ Mononuclear } & $\begin{array}{l}{\left[\mathrm{Pd}(\mathrm{sac})(\text { terpy) }](\mathrm{sac}) \bullet 4 \mathrm{H}_{2} \mathrm{O}(\mathrm{compared} \text { to cDDP and }\right.} \\
\text { paclitaxel); L: saccharinate (sac), 2,2':6',2'”- } \\
\text { terpyridine (terpy) }\end{array}$ & $\begin{array}{l}\text { Balb/c mice } \\
\text { subcutaneously injected } \\
\text { with Ehrlich ascites } \\
\text { carcinoma (EAC) cells } \\
\text { (comparison to in vitro) }\end{array}$ & $\begin{array}{l}\text { * Mild-to-low toxic profile (evaluated through animal weight), } \\
\text { comparable to paclitaxel and less toxic than with cDDP (delays } \\
\text { cancer growth) }\end{array}$ & $(21)$ \\
\hline & $\begin{array}{l}{\left[\mathrm{Pd}(\mathrm{acac})_{2}\right] \text { (compared to cDDP); L: }} \\
\text { bisacetylacetonate (acac) }\end{array}$ & $\begin{array}{l}\text { H460 (lung cancer) } \\
\text { xenograft mouse model } \\
\text { (Balb/c) (comparison to in } \\
\text { vitro) }\end{array}$ & $\begin{array}{l}\text { * Significant toxic profile but lower than with cDDP (better } \\
\text { antitumor activity) }\end{array}$ & $(23)$ \\
\hline Polynucl. & $\begin{array}{l}\mathrm{Pd}_{2}\left[\mathrm{~S}_{(-)} \mathrm{C}^{2}, \mathrm{~N} \text {-dmpa }\right]_{2} \text { ( } \mu \text {-dppe) } \mathrm{Cl}_{2} \text { (compared to } \\
\mathrm{cDDP}) ; \mathrm{L}: \mathrm{N}, \mathrm{N} \text {-dimethyl-1-phenethyl-amine } \\
\text { (dmpa),1,2-ethanebis (diphenylphosphine) (dppe) }\end{array}$ & $\begin{array}{l}\text { Wistar rats and B16F10- } \\
\text { Nex2 (melanoma) } \\
\text { xenograft mice (C57Bl/6) } \\
\text { (comparison to in vitro) }\end{array}$ & $\begin{array}{l}\text { * Wistar rats: disturbed permeabilization of mitochondria } \\
\text { membranes } \\
\text { * Xenograft mice: reduced number of nodules, anti- } \\
\text { metastatic effect }\end{array}$ & $(29)$ \\
\hline
\end{tabular}

ATP, adenosine triphosphate; Bax, Bcl-2-associated X protein; Bcl-2, B-cell lymphoma 2; CAT, catalase; cDDP, cisplatin; CHOP, growth arrest and DNA damage-inducible gene 153 (GADD153); Dox, docetaxel; ER, endoplasmic reticulum; JNK, Jun N-terminal kinase; GPX, glutathione peroxidase; GSH, glutathione (reduced); GST, glutathione transferase; GSTp1, glutathione S-transferase pi; IRE1, inositol-requiring enzyme 1; PARP, poly(ADP-ribose) polymerase (DNA-repair enzyme); PA, polyamine; PLS-DA, partial least squares-discriminant analysis; PC, phosphocholine; PTK, protein tyrosine kinase; MTX, methotrexate; n/a, not applicable; NRF-2, nuclear factor erythroid 2-related factor 2; ROS, reactive oxygen species; SMO, spermine oxidase; SSAT, spermidine/spermine $N^{1}$-acetyltransferase (SSAT-1).

and apoptosis (Table 1). This report on proteomics and subsequent pathway analysis for data interpretation illustrates the large levels of complex information retrievable from the use of untargeted omic approaches.

The epithelian cervical cancer cell line HeLa was also used to test the $\mathrm{Pd}(\mathrm{MCO})_{2}$ complex (with ligand 2-cyano-2-isonitroso$\mathrm{N}$-morpholylacetamide), compared to $\mathrm{Pt}(\mathrm{MCO})_{2}$ (22). Results showed that the complexes induced no change in mitochondrial metabolism, although overall results suggested different metabolic impacts of the $\mathrm{Pd} / \mathrm{Pt}(\mathrm{MCO})_{2}$ complexes, compared to those of cisplatin family. This was interpreted as a possible circumvention of the negative side effects usually associated with cisplatin. A subsequent paper has described the effect of [Pd $(\text { acac })_{2}$ ] (acac: bisacetylacetonate), a Pd-O complex, on several cancer cell lines and, in particular, on human non-small-cell lung cancer H460 cells (23), to investigate the mechanism through which apoptosis was induced. The authors concluded that the apoptotic mechanism did not seem to relate to DNA but, rather, was mediated by endoplasmic reticulum (ER) stress pathway. ER stress increase was reflected by increased expression of the CHOP protein (associated to growth arrest and DNA damageinducible gene 153), known to play a key role on the ER pathway. Since the ER regulates intracellular $\mathrm{Ca}^{2+}$ levels, the lower $\mathrm{Ca}^{2+}$ levels observed upon treatment with the $\mathrm{Pd}(\mathrm{II})$ complex were interpreted as reflecting ER stress, together with accumulation of misfolded protein in ER. The authors suggested that this apoptotic mechanism could be explained by the $\mathrm{Pd}-\mathrm{O}$ nature of the complex (instead of $\mathrm{Pd}-\mathrm{N}$ ), which may prevent interaction with S-ligand- or N-ligand-containing molecules (e.g., DNA). In the same year, a comprehensive study of $\mathrm{Pd}($ diethyl- dithiocarbamate) $)_{2}$, compared to its $\mathrm{Pt}(\mathrm{II})$ analogue and other symmetrical mononuclear $\mathrm{Pt}(\mathrm{II})$ and $\mathrm{Ni}(\mathrm{II})$ complexes (24), on human leukemia cells (K562 cell line) revealed detailed information on glutathione utilization, antioxidant mechanisms and kinase signaling, aiming at investigating the impact on cellular defense mechanisms. Figure $\mathbf{1}$ shows part of the different cellular defense mechanisms believed to be triggered by cisplatin, for instance, and correlate to development of drug resistance. In this study of $\mathrm{Pd}$ (diethyl-dithiocarbamate) $)_{2}$, the activity of several enzymes was measured including for glutathione-transferase (GST) enzymes (associated to drug resistance and cancer development) and protein tyrosine kinase (PTK) (Table 1). Results showed that the extent of antioxidant defense is strongly dependent on the nature of the metal complex, Pd(diethyl-dithiocarbamate) $)_{2}$ exhibiting favorable antioxidant characteristics, in tandem with good antitumor performance. A later systematic study of four Pd(II) [bis-2-(arylazo)phenolates] on human lung carcinoma (A549), cervical carcinoma (HeLa) and teratocarcinoma (PA-1) cell lines (26) helped to single out one of the complexes as the most effective in inducing apoptosis in all cell lines, while causing mitochondrial dysfunction affecting several enzymes and raising ROS levels (Table 1).

Following on earlier studies of $\mathrm{Pd}(\mathrm{II})$ complexes with saccharinate as a ligand $(21,25)$, a more recent report by the same group further exploited the promise of $\mathrm{Pd}(\mathrm{II}) / \mathrm{Pt}(\mathrm{II})$ complexes with saccharinate, now combined with diphoshine ligands (27). A series of neutral and cationic $\operatorname{Pd}(\mathrm{II})$ saccharinate complexes with 1,1-bis(diphenyl-phosphino)methane (dppm) or 1,2-bis(diphenyl diphosphino)ethane (dppe) were synthesized 


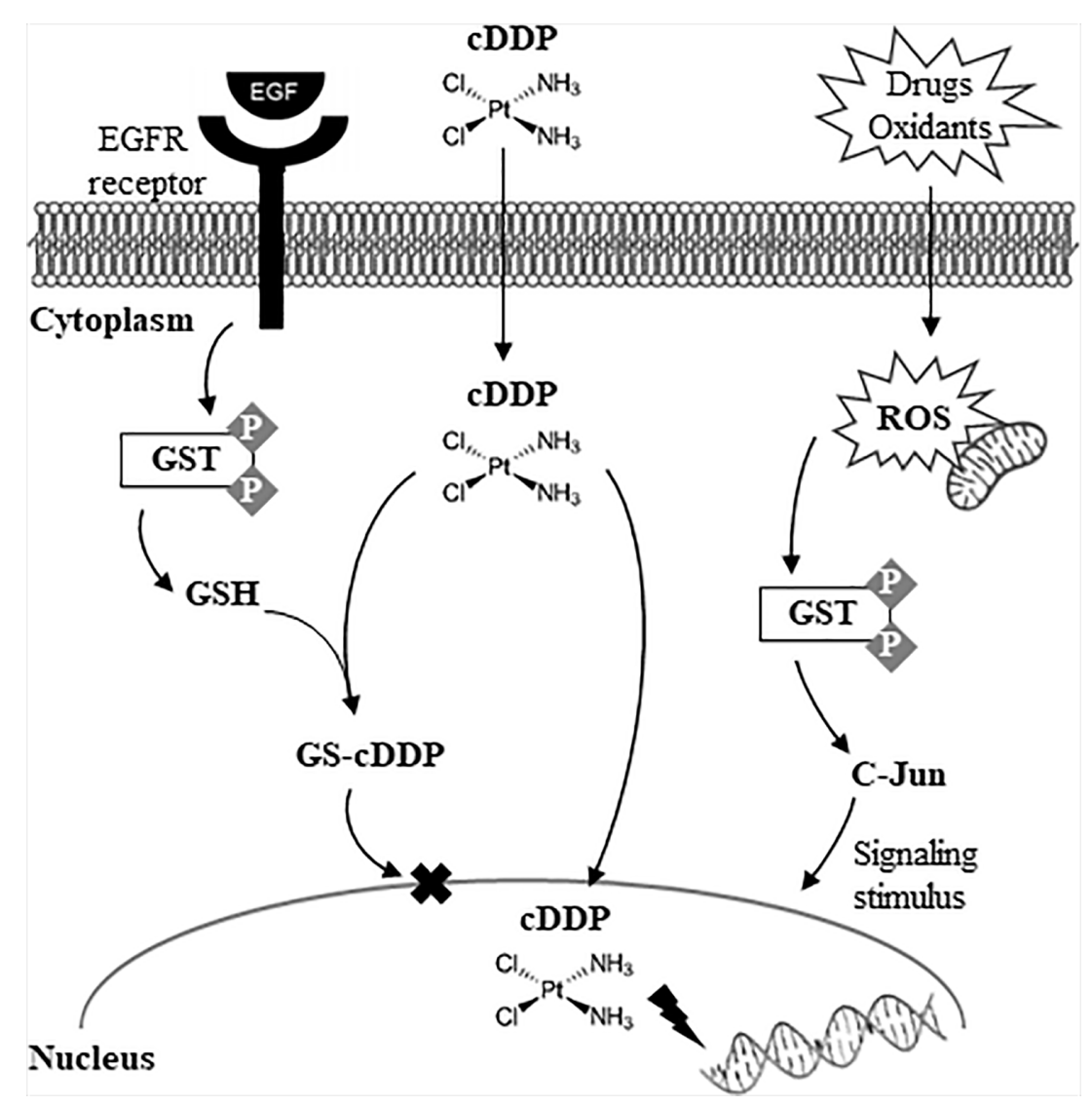

FIGURE 1 | The coordination mechanism of Pt(II)-derived drug cDDP (cisplatin) with GSH and the consequent effect of GST-mediated drug resistance. Adapted from reference (24).

and subsequently tested on several human cancer cell lines: breast (MCF-7), lung (A549), prostate (DU145), colon (HCT116), as well as on healthy bronchial epithelial cells (BEAS-2B). This systematic report enabled the identification of cationic Pd-dppm and Pd-dppe complexes as promising as potential anti-cancer agents, while the former (Pd-dppm, either of neutral or cationic nature) seemed to cause clearer apoptosis, accompanied by cell arrest at the S-phase stage (DNA synthesis) and production of high levels of ROS.

\section{Polynuclear Pd(II) Complexes}

All studies listed for polynuclear $\mathrm{Pd}$ (II) complexes relate to bidentate chelates and most refer to complexes bearing biogenic polyamines (PAs) (Table 1). The exception relates to a study of a biphosphinic cyclopalladated complex with $N$, $\mathrm{N}$-dimethyl-1-phenethyl-amine (dmpa) and 1,2-ethanebis (diphenylphosphine) (dppe) as ligands (29) (Table 1). This complex was tested in vitro on murine melanoma cell lines. The results indicated mitochondrial dysfunction, in tandem with increased cytosolic $\mathrm{Ca}^{2+}$ levels and decreased ATP levels, as well as activation of caspase enzymes, triggering apoptosis.

In relation to biogenic $\mathrm{PA}$ complexes, the $\mathrm{Pd}_{2}$ Spermine $(\mathrm{Spm})$ and $\mathrm{Pt}_{2} \mathrm{Spm}$ bidentate complexes have been compared early on (28) as to their effects on the expression of genes involved in the polyamine pathway. This metabolic pathway has been recognized as an important target for therapeutic strategies since PA are required for cell proliferation and are, thus, usually found elevated in tumor tissues (28). The $\mathrm{Pd}_{2} \mathrm{Spm}$ complex was found to induce a similar effect on several polyamine pathway enzymes as $\mathrm{Pt}_{2} \mathrm{Spm}$, both compounds inducing distinguishing enzymatic profiles compared to cisplatin. Interestingly, $\mathrm{Pd}_{2} \mathrm{Spm}$ induced significant declines in biogenic PA levels, whereas the Pt(II) analogue did not (28), thus pinpointing $\mathrm{Pd}(\mathrm{II}) / \mathrm{PA}$ complexes as promising agents in therapeutic strategies. $\mathrm{Pd}_{2} \mathrm{Spm}$ was subsequently compared to $\mathrm{Pd}_{2} \mathrm{BENSpm}$ [with $\mathrm{PA}$ analogue $N^{1}, N^{11}$-bis (ethyl)norspermine as ligand] and $\mathrm{Pt}_{2} \mathrm{CPENSpm}$ (with $\mathrm{PA}$ analogue $N^{1}$-cyclo-propylmethyl- $N^{11}$-ethylnorspermine), as well as with the free ligands BENSpm and CPENSpm) (10), in relation to its action against both normal (MCF-10A) and breast cancer (JIMT-1, L56BR-C1) cell lines (Table 1). Comparison with normal cell lines is important to evaluate the action of potential anti-cancer drugs on healthy tissue, thus helping to identify effects related to possible side effects. L56BR-C1 cells seemed to be significantly sensitive to Pd(II) complexes, $\mathrm{Pd}_{2} \mathrm{BENSpm}$ inducing decreased $\mathrm{PA}$ levels and 
increased spermidine/spermine $N^{1}$-acetyltransferase (SSAT) activity, whereas $\mathrm{Pd}_{2} \mathrm{Spm}$ induced lower glutathione (GSH) levels (including in other cell lines studied). In addition, $\mathrm{Pd}_{2} \mathrm{BENSpm}$ was found to elicit quite low toxicity toward non-tumorigenic breast epithelial cells $\left(\mathrm{IC}_{50}=34.2 \mu \mathrm{M} v\right.$ s. 7.3 and $0.4 \mu \mathrm{M}$ for breast cancer cell lines), which is a promising result supporting its possible use as an anticancer drug. A later study (30) compared the same $\mathrm{Pd}_{2} \mathrm{Spm}$ and $\mathrm{Pt}_{2} \mathrm{Spm}$ complexes using vibrational spectroscopy and unsupervised multivariate analysis to identify changes in several cellular components. The study identified changes in the levels of cellular lipids and several nitrogen bases, as well as in DNA and protein structure (conformational changes or proteolysis), as resulting from exposure to the spermine-based complexes (Table 1). A more recent study tested $\mathrm{Pd}_{2} \mathrm{Spm}$ on osteosarcoma cells and osteoblasts, compared to cisplatin, using untargeted highresolution-magic-angle-spinning (HRMAS) nuclear magnetic resonance (NMR) spectroscopy metabolomics (31). HRMAS NMR enables the direct analysis of cells, thus providing information simultaneously on polar and apolar components. The Pd(II) complex alone was seen to affect the metabolome of osteoblasts more extensively than that of cancer cells, evidencing no indication of apoptosis, contrary to cisplatin alone. However, when combined with doxorubicin and methotrexate, the $\operatorname{Pd}(\mathrm{II})$ complex impacted more strongly on cancer cells, in a similar way to the equivalent cisplatin-based combination: apoptosis was induced and strong variations were noted in lipids, choline compounds (cell membrane metabolism), several amino acids, nucleotides, and compounds related to antioxidative defense mechanisms (GSH and, possibly, inositol and hypoxanthine). This showed that an untargeted metabolomics strategy can unveil a large number of a priori unknown responsive metabolites (and pathways). In this case, this approach revealed that $\mathrm{Pd}_{2} \mathrm{Spm}$ can impact differently on cell metabolism (of both cancer and healthy cells), depending on whether it is administered alone or combined with other drugs. In fact, the promise of such strategies in revealing hidden features of cellular response to metal complexes with potential anti-cancer action has been recently reviewed, giving particular emphasis to NMR as the chosen analytical technique (32).

\section{IN VIVO STUDIES OF THE METABOLIC IMPACT OF Pd(II) COMPLEXES}

In vivo studies are still few in number and the existing reports tend to describe indirect features of altered metabolism, in comparison with in vitro observations $(21,23,29)$. Three different $\mathrm{Pd}(\mathrm{II})$ complexes have been studied in vivo in murine animal models (all in tandem with in vitro studies) (Table 1): [Pd (sac)(terpy) $]\left(\right.$ sac) $\bullet 4 \mathrm{H}_{2} \mathrm{O},\left[\mathrm{Pd}(\mathrm{acac})_{2}\right]$ and $\mathrm{Pd}_{2}\left[\mathrm{~S}_{(-)} \mathrm{C}^{2}, \mathrm{~N}-\mathrm{dmpa}\right]_{2}$ ( $\mu$-dppe) $\mathrm{Cl}_{2}$. Reports generally indicate that these $\mathrm{Pd}(\mathrm{II})$ complexes induce a lesser toxic profile than cisplatin on animals, as evaluated by animal weight, while performing more effectively in terms of antitumor activity. However, to our knowledge, no further specific metabolic information has been reported on either toxicity or anticancer activity of $\mathrm{Pd}(\mathrm{II})$ complexes in an in vivo context, thus clearly unveiling a niche of research which would be interesting to pursue.

\section{DISCUSSION}

This mini-review has shown that most of the existing knowledge on the effects of $\mathrm{Pd}(\mathrm{II})$ complexes with potential anticancer activity on cell lines has been based on the important understanding of the mechanisms of induced cell death and antioxidant defense. The majority of studies have involved the measurement of changes at the gene and protein expression levels, usually adding measurements of ATP, ROS, and glutathione as markers of antioxidant mechanisms, and, in the specific cases of $\mathrm{Pd}(\mathrm{II})$ complexes with biogenic polyamines, the cellular levels of those compounds. Few reports have, so far, to the best of our knowledge, followed more untargeted approaches, although a tendency is noted for the use of omic sciences such as proteomics and metabolomics, involving analytical techniques such as mass spectrometry, vibrational spectroscopy and NMR spectroscopy. We propose that possible future developments in the context of metal complexes as anti-cancer agents, and particularly the promising $\mathrm{Pd}(\mathrm{II})$ complexes explored so far, may include the more extensive use of untargeted omic sciences, not only limited to study cancer cells but also including healthy/normal cells, in order to evaluate possible underlying metabolism deviations that may give rise to negative side effects. Furthermore, the issue of drug combination may follow naturally, based on studies that have shown how different the impacts of single and combined complexes may be. Finally, an increasing need of translational studies between in vitro and in vivo scenarios becomes clear, although the use of animal models is challenging and costly, with the added challenges of determination of drug doses of relevance and overall interpretation encompassing systemic response. In any case, metabolic players are, undoubtedly, an important part of cell/ organism response and adaptation to therapeutic agents, their further study potentially contributing valuably for a more complete understanding of processes such as biotoxicity or development of drug resistance.

\section{AUTHOR CONTRIBUTIONS}

AG and TC conceived the scope of the manuscript. AG, TC, and $\mathrm{MM}$ were responsible for the literature search and selection, as well as for drafting the manuscript. AM and TC helped with final formatting of the manuscript, graphics and references. All authors contributed to the article and approved the submitted version.

\section{FUNDING}

AG acknowledges funding from the CICECO-Aveiro Institute of Materials project, with references UIDB/50011/2020 \& UIDP/ 
$50011 / 2020$, financed by national funds through the FCT/MEC and when appropriate co-financed by FEDER under the PT2020 Partnership Agreement. MM acknowledges financial support from POCentro, COMPETE 2020, Portugal 2020 and European Community through the FEDER and the Portuguese Foundation for Science and Technology (UIDB/00070/2020). TC and AM are grateful to the Portuguese Foundation for Science and Technology (FCT) for grants SFRH/BD/145920/2019 and SFRH/BD/111576/2015, respectively.

\section{REFERENCES}

1. Rosenberg B, VanCamp L, Trosko JE, Mansour VH. Platinum compounds: a new class of potent antitumour agents. Nature (1969) 222:385-6. doi: $10.1038 / 222385 \mathrm{a} 0$

2. Wiltshaw E. Cisplatin in the treatment of cancer. Platinum Met Rev (1979) 23:90-8.

3. Marques MPM, Gianolio D, Cibin G, Tomkinson J, Parker SF, Valero R, et al. A molecular view of cisplatin's mode of action: interplay with DNA bases and acquired resistance. Phys Chem Chem Phys (2015) 17:5155-71. doi: 10.1039/ C4CP05183A

4. Kostova I. Ruthenium complexes as anticancer agents. Curr Med Chem (2006) 13:1085-107. doi: 10.2174/092986706776360941

5. Braga SS, Marques J, Heister E, Diogo CV, Oliveira PJ, Paz FAA, et al. Carriers for metal complexes on tumour cells: the effect of cyclodextrins vs CNTs on the model guest phenanthroline-5,6-dione trithiacyclononane ruthenium(II) chloride. BioMetals (2014) 27:507-25. doi: 10.1007/s10534-014-9725-8

6. Kostova I. Titanium and vanadium complexes as anticancer agents. Anticancer Agents Med Chem (2009) 9:827-42. doi: 10.2174/187152009789 124646

7. Messori L, Scaletti F, Massai L, Cinellu MA, Gabbiani C, Vergara A, et al. The mode of action of anticancer gold-based drugs: a structural perspective. Chem Commun (Camb) (2013) 49:10100-2. doi: 10.1039/C3CC46400H

8. Vojtek M, Marques MPM, Ferreira I.M.P.L.V.O., Mota-Filipe H, Diniz C. Anticancer activity of palladium-based complexes against triple negative breast cancer. Drug Discovery Today (2019) 24:1044-58. doi: 10.1016/ j.drudis.2019.02.012

9. Silva TM, Andersson S, Kumar S, Marques MPM, Persson L, Oredsson S. Norspermidine and novel $\mathrm{Pd}(\mathrm{II})$ and $\mathrm{Pt}(\mathrm{II})$ polynuclear complexes of norspermidine as potential antineoplastic agents against breast cancer. PloS One (2013) 8:e55651. doi: 10.1371/journal.pone.0055651

10. Silva TM, Fiuza SM, Marques MPM, Person L, Oresson S. Increased breast cancer cell toxicity by palladination of the polyamine analogue $\mathrm{N}_{1}, \mathrm{~N}_{11}$-bis (ethyl)norspermine. Amino Acids (2014) 46:339-52. doi: 10.1007/s00726-0131621-y

11. Batista de Carvalho ALM, Medeiros PSC, Costa FM, Ribeiro VP, Sousa JB, Diniz C, et al. Anti-invasive and anti-proliferative synergism between docetaxel and a polynuclear Pd-spermine agente. PloS One (2016) 11: e0167218. doi: 10.1371/journal.pone.0167218

12. Ray S, Mohan R, Singh JK, Samantaray MK, Shaikh MM, Panda D, et al. Anticancer and antimicrobial metal- lopharmaceutical agents based on palladium, gold, and silver N- heterocyclic carbene complexes. J Am Chem Soc (2007) 129:15042-53. doi: 10.1021/ja075889z

13. Marques MPM. Platinum and palladium polyamine complexes as anticancer agents: the structural factor. ISRN Spectrosc (2013) 2013:1-29. doi: 10.1155/ 2013/287353

14. Fiuza SM, Holy J, Batista de Carvalho LAE, Marques MPM. Biologic activity of a dinuclear Pd(II)-spermine complex toward human breast cancer. Chem Biol Drug Des (2011) 77:477-88. doi: 10.1111/j.1747-0285.2011.01081.x

15. Jovanović S, Obrenčević K, Bugarčić ZD, Popović I, Žakulac J, Petrović B. New bimetallic palladium(II) and platinum(II) complexes: studies of the nucleophilic substitution reactions, interactions with CT-DNA, bovine serum albumin and cytotoxic activity. Dalton Trans (2016) 45:12444-57. doi: $10.1039 / \mathrm{c} 6 \mathrm{dt} 02226 \mathrm{j}$

\section{SUPPLEMENTARY MATERIAL}

The Supplementary Material for this article can be found online at: https://www.frontiersin.org/articles/10.3389/fonc.2020. 590970/full\#supplementary-material

SUPPLEMENTARY TABLE 1 | Compound names and chemical structures of Pd(II) complexes tested for some kind of metabolic effects, either in vitro or in vivo, as listed in Table 1. *: in these cases the structure of the complex could not be found. Compound chemical structures shown were drawn from scratch with basis on the references indicated.

16. Martins A, Batista de Carvalho AL, Lamego I, Marques MPM, Gil AM. Cytotoxicity of platinum and palladium chelates against osteosarcoma. ChemistrySelect (2020) 5:5993-6000. doi: 10.1002/slct.202001361

17. Marques MPM, Batista de Carvalho ALM, Mamede AP, Dopplapudi A, Rudi C S, Tyagi M, et al. A new look into the mode of action of metal-based anticancer drugs. Molecules (2020) 25:246. doi: 10.3390/molecules 25020246

18. Alam MD, Huq F. Comprehensive review on tumour active palladium compounds and structure-activity relationships. Coordin Chem Rev (2016) 316:36-67. doi: 10.1016/j.ccr.2016.02.001

19. Valentini A, Conforti F, Crispini A, De Martino A, Condello R, Stellitano C, et al. Synthesis, oxidant properties, and antitumoral effects of a heteroleptic palladium(II) complex of curcumin on human prostate cancer cells. J Med Chem (2009) 52:484-91. doi: 10.1021/jm801276a

20. Mukherjee S, Chowdhury S, Chattapadhyay AP, Bhattacharya A. Spectroscopic, cytotoxic and DFT studies of a luminescent palladium(II) complex of a hydrazone ligand that induces apoptosis in human prostate cancer cells. Inorg Chim Acta (2011) 373:40-6. doi: 10.1016/j.ica.2011.03.048

21. Ulukaya E, Ari F, Dimas K, Ikitimur EI, Guney E, Yilmaz VT. Anti-cancer activity of a novel palladium(II) complex on human breast cancer cells in vitro and in vivo. Eur J Med Chem (2011) 46:4957-63. doi: 10.1016/ j.ejmech.2011.07.055

22. Ratclif J, Durham P, Keck M, Mokhir A, Gerasimchuk N. Part 2: In vitro cytotoxicity studies of two ML2 complexes $(\mathrm{M}=\mathrm{Pd}, \mathrm{Pt} ; \mathrm{L}=2$-cyano- 2 isonitroso-N-morpholylacetamide, HMCO. Inorg Chim Acta (2012) 385:1120. doi: 10.1016/j.ica.2011.12.004

23. Wang Y, Hu J, Cai Y, Xu S, Weng B, Peng K, et al. An oxygen-chelate complex, palladium bis-acetylacetonate, induces apoptosis in $\mathrm{H} 460$ cells via endoplasmic reticulum stress pathway rather than interacting with DNA. J Med Chem (2013) 56:9601-11. doi: 10.1021/jm4016312

24. Isgor BS, Isgor YG, Yaman-Ozalp S. The role of metal coordination complexes in cytosolic cellular defense. Pure Appl Chem (2013) 85:365-75. doi: 10.1351/ PAC-CON-12-06-10

25. Adiguzel Z, Baykal AT, Kacar O, Yilmaz VT, Ulukaya E, Accilan C. Biochemical and proteomic analysis of a potential anticancer agent: palladium(II) saccharinate complex of terpyridine acting through double strand break formation. J Proteome Res (2014) 13:5240-9. doi: 10.1021/pr5006718

26. Banarjee P, Majumder P, Halder S, Drew MGB, Bhattacharya S, Mazumder S. Comparative anti-proliferative activity of some new 2-(arylazo)phenolatepalladium (II) complexes and cisplatin against some human cancer cell lines. Free Radical Res (2015) 49:253-68. doi: 10.3109/10715762.2014.998665

27. Icsel C, Yilmaz VT, Aygun M, Cevatemre B, Alper P, Ulukaya E. Palladium(II) and platinum)II) saccharinate complexes with bis(diphenylphosphino) methane/ethane: synthesis, S-phase arrest and ROS-mediated apoptosis in human colon cancer cells. Dalton Trans (2018) 47:11397-410. doi: 10.1039/ c8dt02389a

28. Tummala R, Diegelman P, Fiuza SM, Batista de Carvalho LAE, Marques MPM, Kramer DL, et al. Characterization of Pt-, Pd-spermine complexes for their effect on polyamine pathway and cisplatin resistance in A2780 ovarian carcinoma cells. Oncol Rep (2010) 24:15-24. doi: 10.3892/or_00000823

29. Serrano FA, Matsuo AL, Monteforte PT, Bechara A, Smaili SS, Santana DP, et al. A cyclopalladated complex interacts with mitochondrial membrane thiol-groups and induces the apoptotic intrinsic pathway in murine and cisplatin-resistant human tumor cells. BMC Cancer (2011) 11:296. doi: 10.1186/1471-2407-11-296 
30. Batista de Carvalho ALM, Pilling M, Gardner P, Doherty J, Cinque G, Wehbe K, et al. Chemotherapeutic response to cisplatin- like drugs in human breast cancer cells probed by vibrational microspectroscopy. Faraday Discuss (2016) 187:27398. doi: 10.1039/c5fd00148j

31. Lamego I, Marques MPM, Duarte IF, Martins AS, Oliveira H, Gil AM. Impact of the $\mathrm{Pd}_{2}$ spermine chelate on osteosarcoma metabolism: an NMR metabolomics study. J Proteome Res (2017) 16:1773-83. doi: 10.1021/ acs.jproteome.7b00035

32. De Castro F, Benedetti M, Del Coco L, Fanizzi FP. NMR-based metabolomics in metal-based drug research. Molecules (2019) 24:2240. doi: 10.3390/ molecules 24122240
Conflict of Interest: The authors declare that the research was conducted in the absence of any commercial or financial relationships that could be construed as a potential conflict of interest.

Copyright (c) 2020 Carneiro, Martins, Marques and Gil. This is an open-access article distributed under the terms of the Creative Commons Attribution License (CC BY). The use, distribution or reproduction in other forums is permitted, provided the original author(s) and the copyright owner(s) are credited and that the original publication in this journal is cited, in accordance with accepted academic practice. No use, distribution or reproduction is permitted which does not comply with these terms. 